Egyptian Journal of Aquatic Biology \& Fisheries

Zoology Department, Faculty of Science,

Ain Shams University, Cairo, Egypt.

ISSN $1110-6131$

Vol. 25(2): 735 - 769 (2021)

www.ejabf.journals.ekb.eg

\title{
Bioflocculant production by marine psychrotolerant Psychrobacter cibarius H41A KF207755 with its special role in silver nanoparticles production
}

\author{
Amal M. Hassan ${ }^{1}$, Ghada E. Hegazy ${ }^{2 *}$, Gehan M. Abu Elela ${ }^{2}$, Hanan M. Abd El Naby ${ }^{2}$, \\ Yousrah Yasser M. Dusuki ${ }^{3}$ and Hassan A.H. Ibrahim ${ }^{2}$ \\ ${ }^{1}$ Department of Microbiology, Faculty of Science, Alexandria University, Egypt. \\ ${ }^{2}$ Marine Microbiology Department, National Institute of Oceanography and Fisheries (NIOF), \\ Alexandria Branch, Alexandria, Egypt. \\ ${ }^{3}$ Clinical Pharmacy, Alexandria University, Egypt. \\ "Corresponding Author: ghada19832006@yahoo.com
}

\section{ARTICLE INFO \\ Article History: \\ Received: Jan. 15, 2021 \\ Accepted: April 23, 2021 \\ Online: April 30, 2021}

Keywords:

Bioflocculant

Marine bacteria

Psychrobacter cibarius

Nanoparticles.

\section{INTRODUCTION}

The present study screened 23 previously isolated and identified marine psychrotolerant bacterial strains for the production of bioflocculant. Factors affecting the production process as well as the bioflocculant activity, in addition to the biosynthesis and the characterization of silver AgNPs were carried out. Psychrobacter cibarius H41 AKF207755 exhibited high bioflocculation activity at $75.3 \%$. The effect of different physical and nutritional factors on the bioflocculant production process by $P$. cibarius H41Awas determined. The bioflocculating activity was increased to $82.1 \%$ after incubation for $60 \mathrm{~h}$ and to $84.7 \%$ at $\mathrm{pH}$ 6.5. Also, sucrose and urea improved the activity. The type of cations, $\mathrm{pH}$ level, and temperature were examined on the produced bioflocculant, which reached to $90.3 \%$ at $\mathrm{pH} 9$ and to $92.1 \%$ at $70^{\circ} \mathrm{C}$. The addition of $\mathrm{FeSO}_{4}$ raised the bioflocculant activity up to $94.0 \%$. The concentrations of total protein, total carbohydrate, and total lipid were estimated for the partially purified bioflocculant as; 20.285, 31.215, and $12.2 \mathrm{gL}^{-1}$, respectively. It was found that the AgNPs can be synthesized using the bioflocculant, which remains stable for up to 16 months. Characterization of these AgNPs by UV-spectroscopy, FTIR, and TEM analyses takes place. The $\mathrm{pH} 11$ supported the maximum synthesis of $\mathrm{AgNPs}$ at $2 \mathrm{mM} \mathrm{AgNO}_{3}$. TEM revealed that the size of the produced AgNPs ranged from $1.31 \mathrm{~nm}$ to $17.45 \mathrm{~nm}$ and no agglomeration was observed. Upon the applicable level, the antimicrobial property of AgNPs synthesized by the bioflocculant of $P$. cibarius H41A KF207755 was confirmed. The concentration dosage that gave the optimum flocculating activity $(92.5 \%)$ was $4.0 \mathrm{mgmL}^{-1}$.

Bioflocculation is a process, in which separation of solid liquid mixture is achieved by the whole microorganisms or their by-products so-called bioflocculants (Gao et al.,2006). Microbial bioflocculant is an extracellular polymer produced by several microorganisms during their growth, resulting in the formation of stable aggregates of flocs. These bioflocculants has different polymeric substances such as, 
exopolysaccharide, polysaccharides, glycoproteins, protein, nucleic acid and cellulose (Jie et al., 2006). Bioflocculants have been established to be produced by various microbes such as bacteria, actinomycetes, fungi, and algae (Deng et al., 2003; Xia et al., 2008). Early, there was a great interest in studying bioflocculants to replace the hazardous synthetic flocculants because of their benefits as biodegradable, safe, and eco-friendly biopolymers (Deng et al., 2003; Bhunia et al., 2012).

Many studies have been reported on bioflocculants in the industrial sector. They are effectively applied in the drinking and wastewater treatment, downstream processing, and fermentation processes, reduction of water pollution and in aquaculture treatment (Shahadat et al., 2017; Hashim et al., 2019). They are used in the field of wastewater treatment for removing suspended solids and metal ions, at which colloids come out of suspension in the form of flocs or flakes (Li et al., 2003). For instance, it was found that that the bioflocculants produced by Alcaligenes latus had the ability to absorb water 1000 times of its weight and 5 times stronger than that of synthetic absorber polymers (Kurane and Nohata, 1997). The production of bioflocculants has been studied and then applied in the batch fermentation like many biological products such as amino acids, vitamins and enzymes. However, there have been few reports on the biosynthesis of flocculants on a pilot scale (Patrick and Finn, 2008; Abd El-Salam et al., 2017).

On the other side, many microorganisms including bacteria (Mathias et al., 2017), fungi (Shahverdi et al., 2007), actinomycetes (Silambarasan and Abraham, 2013), and algae (Landage and Wasif, 2012) can aggregate inorganic materials and used for green synthesis of AgNPs intracellularly or extracellularly. Indeed, microbial polysaccharides such as bioflocculants are a promising alternative for the synthesis and stabilization of nanoparticles (Sathiyanarayanan et al., 2013). In particular, this is an interesting area of research where both biosynthetic AgNPs and bioflocculants are economically important (Zaki et al., 2014).

The present study investigated the production and optimization of bioflocculant by marine psychrotolerant Psychrobacter cibarius H41A KF207755. In addition, the produced bioflocculant was characterized via standard tools. Studying some valuable applications such as production of highly stable bactericidal AgNPs was accomplished.

\section{MATERIALS AND METHODS}

\section{Media and culture conditions}

The pre-culture and flocculants production media used during this study were mentioned in the work of Luo et al. (2016). The enrichment medium included $\left(\mathrm{gL}^{-1}\right)$; beef extract, 3; peptone,10; and $\mathrm{NaCl}, 5$; and it was amended with $1.8 \%$ agar. ii) The fermentation medium included ( $\mathrm{gL}^{-1}$ ): glucose, $20 ; \mathrm{KH}_{2} \mathrm{PO}_{4}, 1 ; \mathrm{K}_{2} \mathrm{HPO}_{4}, 2 ; \mathrm{MgSO}_{4} .7 \mathrm{H}_{2} \mathrm{O}$, $0.5 ;\left(\mathrm{NH}_{4}\right)_{2} \mathrm{SO}_{4}, 0.2 ; \mathrm{NaCl}, 0.1 ;$ urea, 0.5 and yeast extract, 0.5 . 


\section{Screening of bioflocculant production}

Twenty three different strains of bacteria that previously isolated and identified by NIOF stuff members (Abdelnaby et al., 2019) were screened. Selection of bioflocculant producers were based on the mucoid morphology of appeared and obvious microbial colonies. Subsequently, selected colonies were cultured in broth medium at $30^{\circ} \mathrm{C}$ in a rotary shaker at $120 \mathrm{rpm}$ for $24 \mathrm{~h}$. Then, $2 \mathrm{~mL}$ inoculum of the pre-cultures with optical density $\left(\mathrm{OD}_{550}\right) \mathrm{nm}$ was adjusted at 1.0 were transferred into new flasks containing $50 \mathrm{ml}$ of fermentation medium and re-incubated as described above for 3 days. After the cultivation period, the fermented broth was centrifuged $\left(5000 \mathrm{rpm}, 30 \mathrm{~min}, 4^{\circ} \mathrm{C}\right)$ to separate the bacterial cells and the cell-free supernatant was assessed for flocculating activity.

\section{Determination of bioflocculation efficiency}

A protocol of Kurane et al. (1994) is used to determine the bioflocculating activity, a mixture of $2 \mathrm{ml}$ of the culture broth of selected strains, $5 \mathrm{~mL}$ of $\mathrm{CaCl}_{2}(1 \%$, w/v), and 93 $\mathrm{mL}$ of kaolin $\left(5 \mathrm{gL}^{-1}\right.$ distilled water) suspension were mixed in a $200-\mathrm{mL}$ beaker. A control experiment without bioflocculant was carried out. The mixture was stirred at 180 rpm $\min ^{-1}$ for $1.5 \mathrm{~min}$ and at $80 \mathrm{rpm} \min ^{-1}$ for $3 \mathrm{~min}$ with a vortex mixer (QL-861, Shanghai Jingmi Instrument Co., Ltd., China) and then kept still for $10 \mathrm{~min}$. A sample for optical densities (OD) measurement was withdrawn using automatic pipette from a height of $1 \mathrm{~cm}$ below the surface of clay suspension. The bioflocculation activity of the different isolated strains was screened relying on the upper phase OD for clay suspension that was measured at $550 \mathrm{~nm}$ with a spectrophotometer. The flocculating efficiency was calculated according to the following equation:

Bioflocculation activity $=(\mathrm{B}-\mathrm{A}) / \mathrm{B} \times 100$, where; $\mathrm{A}$ and $\mathrm{B}$ are ODs of the culture sample and the control, respectively.

\section{Factors affecting bioflocculant production process}

The effect of the incubation period on the bioflocculant production of the most promising strains was assessed for different time intervals (12, 24, 36, 48, 60, and $72 \mathrm{~h}$ ). However, the production medium was adjusted at $\mathrm{pH} 7$ and $30^{\circ} \mathrm{C}$. To evaluate the effect of a gradual change in $\mathrm{pH}$ levels on the bioflocculant production, $\mathrm{pH}$ was adjusting by using $0.1 \mathrm{M} \mathrm{HCl}$ and $0.1 \mathrm{M} \mathrm{NaOH}$ at the $\mathrm{pH}$ range of 5-9 (Zheng et al., 2008). In addition, different carbon sources (sucrose, dextrose, xylose, starch, and glucose) were examined to determine the most suitable. All flasks were incubated in a rotary shaker at $120 \mathrm{rpm}$ at $30^{\circ} \mathrm{C}$ with the optimum incubation period. To elucidate the effects of nitrogen source, urea was replaced by peptone, ammonium chloride, and potassium nitrate. These different nitrogen sources were employed with the most suitable carbon source then examined to determine which maximize the production of bioflocculant. All flasks were 
incubated at the optimum conditions. Cells were removed by centrifugation then the bioflocculant activity was measured in the supernatants.

\section{Extraction and purification of bioflocculant}

Adopting the method of Kurane et al. (1994), the extraction of the bioflocculant was performed. Briefly, after $60 \mathrm{~h}$ of fermentation, the culture broth was centrifuged (5000 rpm, $30 \mathrm{~min}$ ) to remove the bacterial cells. Two volumes of ethanol were later added to the supernatant, stirred and left to stand for $12 \mathrm{~h}$ at $4^{\circ} \mathrm{C}$. The supernatant was discarded and the pellets were centrifuged at $5000 \mathrm{rpm}, 30 \mathrm{~min}$. In addition, the precipitate obtained was vacuum-dried to obtain crude bioflocculant. Finally, two volumes of ethanol were added to recover the precipitate and then lyophilized.

\section{Effect of pH, temperature, and cations on bioflocculant activity}

To study the effect of the different $\mathrm{pH}$ levels on the flocculating activity of bioflocculant produced, the $\mathrm{pH}$ of the kaolin clay suspension was gradually changed from 2 to 11 using $0.1 \mathrm{M} \mathrm{HCl}$ and $0.1 \mathrm{M} \mathrm{NaOH}$ (Zheng et al., 2008). Also, heat stability was evaluated by incubating the bioflocculant solutions in water bath at a temperature range of $30,40,50,60,70$, and $80^{\circ} \mathrm{C}$ for $25 \mathrm{~min}$. Afterwards, the residual flocculating activity was determined using the protocol of Kurane et al. (1994). Additionally, the effect of different cations on bioflocculant production was assessed by replacing $\mathrm{CaCl}_{2}$ in the production medium with $\mathrm{Na}^{+}, \mathrm{K}^{+}, \mathrm{Mg}^{2+}, \mathrm{Mn}^{2+}, \mathrm{Fe}^{2+}$, and $\mathrm{Fe}^{3+}$ using the method of Agunbiade et al. (2017).However, different salts used were: $\mathrm{MgSO}_{4}, \mathrm{FeSO}_{4}, \mathrm{FeCl}_{3}$, $\mathrm{MnSO}_{4} \cdot 7 \mathrm{H}_{2} \mathrm{O}, \mathrm{KCl}$, and $\mathrm{NaCl}$.

\section{Characterization of purified bioflocculant}

The protein concentrations of the biopolymers were determined according to Bradford method (Bradford, 1976). Total sugars were determined by the phenol-sulfuric acid reaction using the procedure of Chaplin and Kennedy (1994). Total lipids were determined according to Frings et al. (1971). Also, sample was metalized with a thin gold film using sputtering device (JFC-1100 E JOEL, USA) for 12 min. Scanning electron microscopy was performed with JSM 5300 JOEL, USA Scanning Electron Microscope at $20 \mathrm{kV}$ in the Centre Laboratory, City of Scientific Research and Technological Applications-Alexandria, Egypt. In addition, the purified bioflocculant was measured on a $\mathrm{KBr}$ disk with a Perkin-Elmer series 1600 to fourier transmission infrared spectroscopy (FTIR) in Attenuated Total Reflection(ATR) mode (500-4000 $\mathrm{cm}^{-1}$ ) to determine the functional groups of such biopolymer. In addition, its scanning electron microscopic images were taken at $5 \mathrm{kV}$ with a FE-SEM (Zeiss, P-Sigma, Germany). 


\section{Biosynthesis of silver nanoparticles}

Fifty milliliters of aqueous solution of $0.5,1.0$, and $2.0 \mathrm{mM} \mathrm{AgNO}_{3}$ were separately treated with $50 \mathrm{~mL}$ of $P$. cibarius $\mathrm{H} 41 \mathrm{~A}$ supernatant solution in a $250 \mathrm{~mL}$ Erlenmeyer flask. The whole mixture was put into a shaker at $30^{\circ} \mathrm{C}(120 \mathrm{rpm})$ for 1 day and maintained in the dark conditions. The control was maintained without addition of $\mathrm{AgNO}_{3}$ with the experimental flask containing bioflocculant. The extracellular synthesis of AgNPs was monitored by visual inspection of flasks for the change in color of the bioflocculant from a clear light yellow to brown (Ahmadet al., 2003). Synthesis of AgNPs was optimized with different pHs.

\section{Characterization of AgNPs}

The synthesized AgNPs were first characterized by UV-visible spectrophotometer (Perkin-Elmer, Germany) between 200-800 nm. In addition micrographs of synthesized AgNPs were obtained using Hitachi H-7500 transmission electron microscope and Jeol JSM-5300 scanning electron microscope (Sathiyanarayanan et al., 2013).

\section{Antimicrobial application of AgNPs}

The well-cut diffusion technique was used to evaluate the antimicrobial activity of the produced AgNPS against the microbial pathogens (Staphylococcus aureus ATCC 25923, Escherichia coli ATCC 8739, Pseudomonas aeruginosa ATCC 9027, Bacillus subtilis ATCC 6633, Enterococcus faecalis ATCC 29212, Klebsilla pneumonia ATCC 13883, and Candida albicans ATCC 10231), separately. All plates were incubated at $37^{\circ} \mathrm{C}$ for 24 h. An inhibition zone (mm) was recorded as positive (Amer and Hassan, 2019).

\section{Effect of storage conditions}

The produced AgNPs was tested after storage at cold condition (stored in a $4^{\circ} \mathrm{C}$ fridge). The antibacterial effect was tested every 45 days where the sample was relatively less frequently exposed to the air (Korshed et al., 2018). Also, the stability of the produced AgNPS was confirmed after 16 months of storage at the fridge by the UV-vis spectrophotometry.

\section{Jar test determination of bioflocculant dosage}

Different concentrations $\left(0.3\right.$ to $\left.5.0 \mathrm{mgmL}^{-1}\right)$ of the partially purified bioflocculant were prepared and their flocculating activities measured against $5 \mathrm{gL}^{-1}$ kaolin clay suspension as previously mentioned by Kurane et al. (1994).

\section{RESULTS}

\section{Screening of bioflocculant production}

Twenty-three marine bacterial strains, previously isolated and identified, were screened for bioflocculant property (Table 1). The selection of the bioflocculant producers was based on the mucoid morphology of appeared and obvious microbial colonies. Visually, eight isolates characterized by the mucoid appearance, where 3 isolates showed high bioflocculation activity $(P$. cibarius H41A KF207755, $P$. pacificensis H62, and $P$. vallis H65). However, these three isolates were selected for 
further investigation. The results in Table (2) found that the bioflocculating activity ranged between 61.5 and $75.3 \%$. Also, the results showed that the isolate $P$. cibarius H41A KF207755 (Fig. 1) was the most active (75.3\%), followed by $P$. pacificensis $\mathrm{H} 62$ (70.4\%). So, P. cibarius H41A was chosen for further investigations. The marine psychrotolerant Psychrobacter cibarius H41A KF207755 was applied in the current study to produce a potent bioflocculant, which had unique characteristics qualifying it to valuable applications. Our results were in the same direction with many previous studies which reported that several bacterial strains able to produce bioflocculants (Elkady et al., 2011; Zaki et al., 2011; Abd El-Salam et al., 2017).

Table 1. Mucoid appearance (MA) for the tested marine bacterial strains.

\begin{tabular}{lclc}
\hline Isolates codes & MA & Isolates codes & MA \\
\hline Pseudomonas sp. H20 & - & Pseudomonas sp. H20S & - \\
Pseudomonas sp. H26S & - & Pseudomonas sp. H69A & + \\
Pseudomonas sp. H44 & + & Psychrobacter cibarius H41A KF207755 & + \\
Pseudomonas sp. H45A & - & Psychrobacter sp. H62 & + \\
Pseudomonas sp. H49 & - & Psychrobactersp. H65 & + \\
Pseudomonas sp. H50 & - & Stenotrophomonas sp. H43S & + \\
Pseudomonas sp. H60 & - & Halomonas sp. H68 & - \\
Pseudomonas sp. H64 & - & Paracoccus sp. H26A & + \\
Pseudomonas sp. H73 & - & Planomicrobium sp. H44A & - \\
Pseudomonas sp. H67S & + & Planomicrobium sp. H71 & - \\
Pseudomonas sp. H67 & - & Pseudoalteromonas sp. H43 & - \\
\hline
\end{tabular}

Table 2. bioflocculating activity of the most potent producers.

\begin{tabular}{lc}
\hline Bacterial strain & Bioflocculating activity ${ }^{*}(\boldsymbol{\%})$ \\
\hline Psychrobacter cibarius H41A KF207755 & 75.3 \\
Psychrobacter pacificensis H62 & 70.4 \\
Psychrobacter vallis $\mathrm{H} 65$ & 61.5 \\
\hline
\end{tabular}

\section{Factors affecting bioflocculant production by P.cibarius H41A KF207755}

The effect of different physical factors such as different incubation periods and $\mathrm{pH}$ on the bioflocculant production process by $P$. cibarius H41A KF207755 was determined. Also, the effect of different carbon and nitrogen sources on bioflocculant production by P. cibarius H41A KF207755 was estimated. The results in Fig. (1A) and Fig. (1B) exhibited that the bioflocculating activity was increased to 82.1 and $84.7 \%$ after incubation for $60 \mathrm{~h}$ at $\mathrm{pH}$ 6.5, respectively. Additionally, sucrose improved the bioflocculating activity to $88.2 \%$ followed by glucose and dextrose (Fig. 1C). The data presented in Fig. (1D) demonstrated that, none of the tested nitrogen sources was comparable to urea with respect to bioflocculating activity.

Bioflocculants can be distinguished into either primary or secondary metabolites depending on the period of secretion in the culture broth (Salehizadeh and Yan, 2014). Maximum production in our results achieved after $60 \mathrm{~h}$ and that agreed with Gong et al. (2008) who reported that a bioflocculant produced by Serratiaficaria reached its maximum flocculating activity in the early stationary phase $(72 \mathrm{~h})$ and subsequently 
observed a slow decrease after $84 \mathrm{~h}$ which was attributed to autolysis and enzymatic activity. The majority of reported studies in the literature revealed that bioflocculants are produced during active growth phase of microorganisms (Salehizadeh and Yan, 2014). On the other hand, the bioflocculant produced by Chryseobacter iumdaeguense W6 was associated with cell autolysis and not cell growth (Liu et al., 2010), running parallel to the profile of flocculating activity. It is known that, $\mathrm{pH}$ dependence for bioflocculant production differed with various microorganisms because the nutrient uptake and enzymatic activity of microorganisms could be influenced by initial $\mathrm{pH}$ of the medium that affected the electric charge of microbial cells and also the oxido-reduction potential (Xia et al., 2008).

(A)
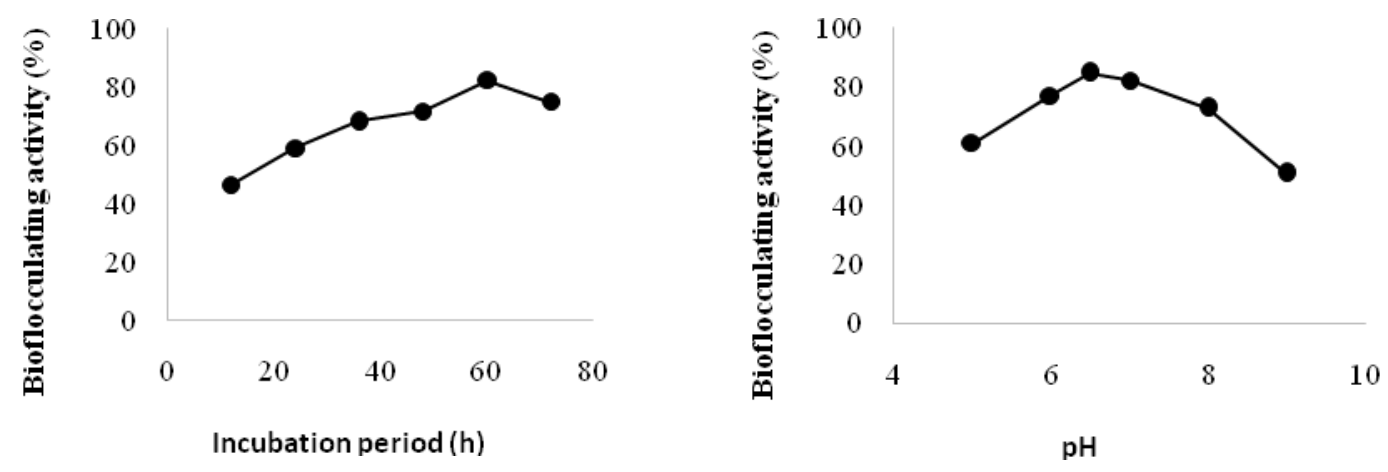

(B)
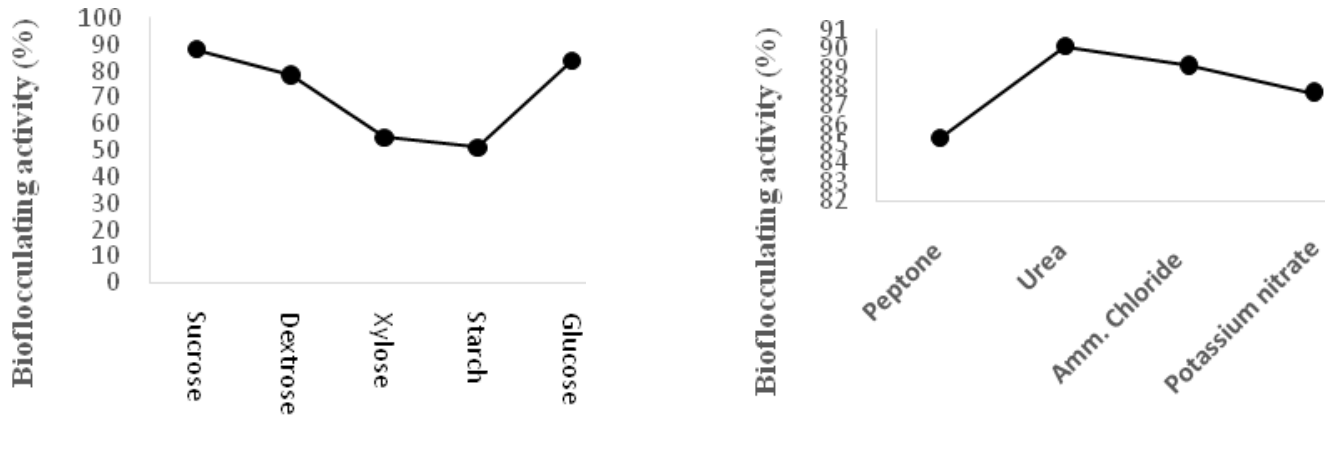

Carbon source

Nitrogen source

Fig. 1. Effect of different incubation period and $\mathrm{pH}(\mathrm{A}) \&$ carbon source and nitrogen source (B) on the production of bioflocculant by P. cibarius H41A KF207755.

The highest bioflocculant activity record was at $\mathrm{pH}$ 6.5. Abd El-Salam et al. (2017) statedthat the $\mathrm{pH}$ values among 7-9 were the optimum, while the acidic and/or alkalinic $\mathrm{pH}$ caused reduction in flocculating activity. The same authors revealed that different carbon sources were noticed to influence the bioflocculant PSK1 production. They observed that the most favorable carbon sources enhancing the bioflocculant production were glucose and maltose. Moreover, they detected that among examined nitrogen 
sources, the organic in particular yeast extract were more suitable than inorganic nitrogen sources for the bioflocculant PSK1 production. These results disagreed with our results which showed that the $P$. cibarius H41A KF207755 gave the highest activity in culture medium amended with urea (90.1\%). In addition, nitrogen sources such as $\mathrm{NaNO}_{3}$, $\mathrm{NH}_{4} \mathrm{Cl}$, and urea stimulate the growth of Klebsiella sp. ZZ-3, allowing the production of glycoprotein with flocculating activity ranging from $90.4 \%$ to $94.5 \%$ (Yin et al., 2014).

The $\mathrm{pH}$ of reaction mixtures is a key factor influencing the flocculation process (Zaki et al., 2013) by affecting the stability of suspended particles and floc formation (Ugbenyen et al. 2014). In particular, our findings demonstrates that acidic and basic $\mathrm{pH}$ media support flocculating efficiency, with the most pronounced activity observed in the basic medium at $\mathrm{pH}$ 9. This observation corroborates the fact that bioflocculants exhibit varying degree of electrical states at different $\mathrm{pH}$ which impact on the flocculating activity of the bioflocculant for kaolin particles (Pan et al., 2009). These results were found to be similar to the observations reported by Ugbenyen et al. (2014), in which the flocculating activity of the bioflocculant produced by a consortium of Cobetia and Bacillus species was over $70 \%$ across a wide $\mathrm{pH}$ range of 3-11 with the highest flocculating activity attained at $\mathrm{pH} 8$.

In addition, thermal stability in the bioflocculating activity up to $70^{\circ} \mathrm{C}$ were detected, however, $18.3 \%$ of bioflocculating activity was lost at $80^{\circ} \mathrm{C}$ after heating for $25 \mathrm{~min}$. These results suggest that the main backbone of the bioflocculant is a polysaccharide. Likewise, the results of the biochemical analysis of the purified bioflocculant confirmed that $31.21 \%$ of polysaccharide was detected. This is consistent with the reported findings that flocculants rich in polysaccharide are more heat-stable than those composed of mainly protein and nucleic acids (Gaoet al., 2009; Wang et al., 2013). Liu et al. (2010) confirmed that the flocculating activity was slightly decreased by $2.9 \%$ after heating the bioflocculant at $80^{\circ} \mathrm{C}$ for $45 \mathrm{~min}$. This decline in activity may be due to that the polysaccharide chain of the bioflocculant could be degraded at high temperature which reduced the ability of bioflocculant to form bridges with suspended particles. Also, Tang et al. (2014) stated that high temperature could denature the protein fraction of the biopolymer which reduced the flocculating efficiency. The results obtained by Abd ElSalam et al. (2017) elucidated that the bioflocculant PSK1 was thermally stable when heated at the temperature range of $40-80^{\circ} \mathrm{C}$ of various time periods. The flocculating activity showed an increase of $1 \%$ more than that of the control after heating the bioflocculant at $70^{\circ} \mathrm{C}$ for $25 \mathrm{~min}$. This result may be due to the release of poly-substances when the biopolymer was heated at higher temperature (Gong et al., 2008).

\section{Factors affecting the activity of produced bioflocculant}

In general, there were three factors investigated on the bioflocculant activity. They were $\mathrm{pH}$ level, temperature and type of cations. However, the data are shown in Fig. (2). The bioflocculant activity increased to $90.3 \%$ at $\mathrm{pH} 9$ and to $92.1 \%$ at $70^{\circ} \mathrm{C}$. Also, the addition of $\mathrm{FeSO}_{4}$, as cation, raised the bioflocculant activity up to $94.0 \%$. 
Basically, it seems that the monovalent and divalent cations help to neutralize negative charges on bioflocculant and the suspended kaolin particles, shortening the distance between them, increasing the initial adsorption ofbioflocculant onto the kaolin particle and thus leading to floc formation and sedimentation (Yim et al., 2007). There have been several reports on divalent cations stimulating the flocculating activity of bioflocculants (Nwodo et al. 2012), on the other hand, very few bioflocculants have been reported to have a high flocculation rate without cations' aid (Zhao et al., 2013). Ugbenyen and Okoh (2014) also reported that the divalent cations tested $\left(\mathrm{Ca}^{2+}, \mathrm{Mg}^{2+}\right.$, and $\mathrm{Mn}^{2+}$ ) were the best metal ions that enhanced the activity of the bioflocculant produced by the consortium of the Cobetiaa and Bacillus species which in turn was completely inhibited by $\mathrm{Li}^{2+}$ and $\mathrm{K}^{2+}$. We can say that high percentage of the results of the previously mentioned authors agreed with our results such as enhancing the flocculating activity in presence of $\mathrm{Ca}^{2+}$ and $\mathrm{Mn}^{2+}$ and reduction of the activity in presence of $\mathrm{K}^{2+}$ and $\mathrm{Fe}^{3+}$.
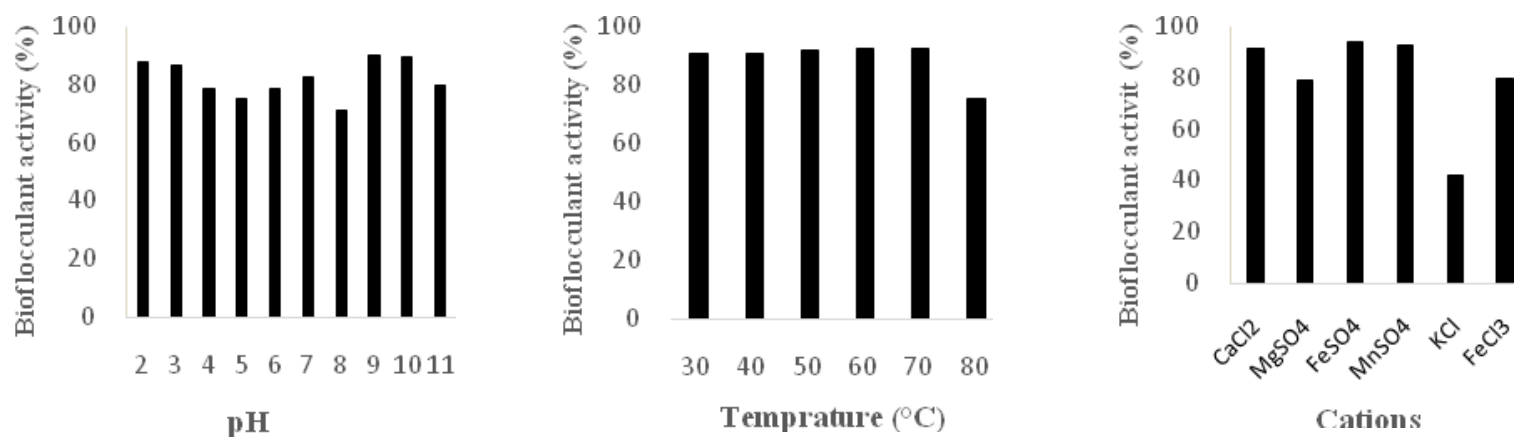

Fig. 2. Effect of different $\mathrm{pH}$, temperature and cations on the activity of the produced bioflocculant by $P$. cibarius H41A KF207755.

\section{Characterization of $\boldsymbol{P}$. cibarius H41AKF207755 biofloculant}

The concentrations of total protein, total carbohydrate, and total lipid were estimated for the bioflocculant produced by $P$. cibarius H41A KF207755. The values of them were; $20.285,31.215$, and $12.2 \mathrm{gL}^{-1}$, respectively. Other means such as; characterization of the partially purified bioflocculant of $P$. cibarius H41A KF207755 was determined by taking SEM images as shown in Fig. (3). The purified bioflocculant appeared as whitish flakes structure (Fig. 3A), the Kaolin clay particles appeared in Fig. 3B. The interaction of the purified bioflocculant and the kaolin particles resulted into compacted flocs formation (Fig. 3C), because of the adsorption of the kaolin particles on the binding sites of the purified bioflocculant and the subsequent interactions resulted into agglomeration of larger flocs. 

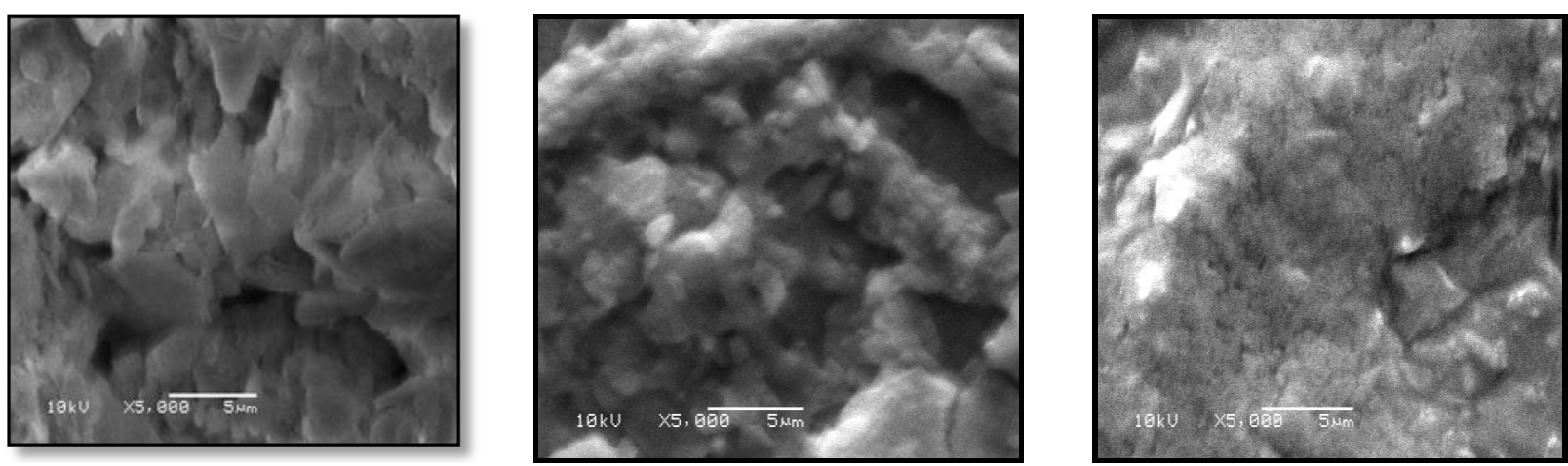

Fig. 3. SEM macrograph showing the features of: (A) purified biofloculant produced by $P$. cibarius $\mathrm{H} 41 \mathrm{~A}$ KF207755: (B) kaolin powder suspension only, and (C) the partially purified bioflocculant flocculating kaolin suspension.

Also, FTIR spectroscopy analyses were performed to elucidate the chemical structure and the essential functional groups of the partially purified $P$. cibarius H41A KF207755 bioflocculant (Fig. 4). The FTIR spectroscopic analyses showed the presence of different and many chemical groups in the bioflocculant as shown in Fig. (5). The strong peaks at $1049.31 \mathrm{~cm}^{-1}$ and $3417.01 \mathrm{~cm}^{-1}$ are characteristic of $-\mathrm{COO}-$ group and (amides or amines) respectively. The weak peaks appearing at $1401.33 \& 1406.15$ and $2457.39 \mathrm{~cm}^{-1}$ correspond to $\mathrm{O}-\mathrm{H}$ group characteristic for carboxylic acid. The spectral signals at $1520.92,1573.97 \mathrm{~cm}^{-1}$ refers to $(\mathrm{C}-\mathrm{N}$ or $\mathrm{N}-\mathrm{H}$ bending $)$ and the strong peaks at 1644.37 \& 1648.23 correspond to $(\mathrm{C}=\mathrm{O}$ stretching $)$. The spectral signals at $2457.39 \mathrm{~cm}^{-1}$ corresponding to $\mathrm{CH}_{3}$ stretching, also a weak peak observed at $2366.74 \mathrm{~cm}^{-1}$. Another weak C-H stretching vibration band was observed at 2927.08 and $2956.97 \mathrm{~cm}^{-1}$ representing alkane.

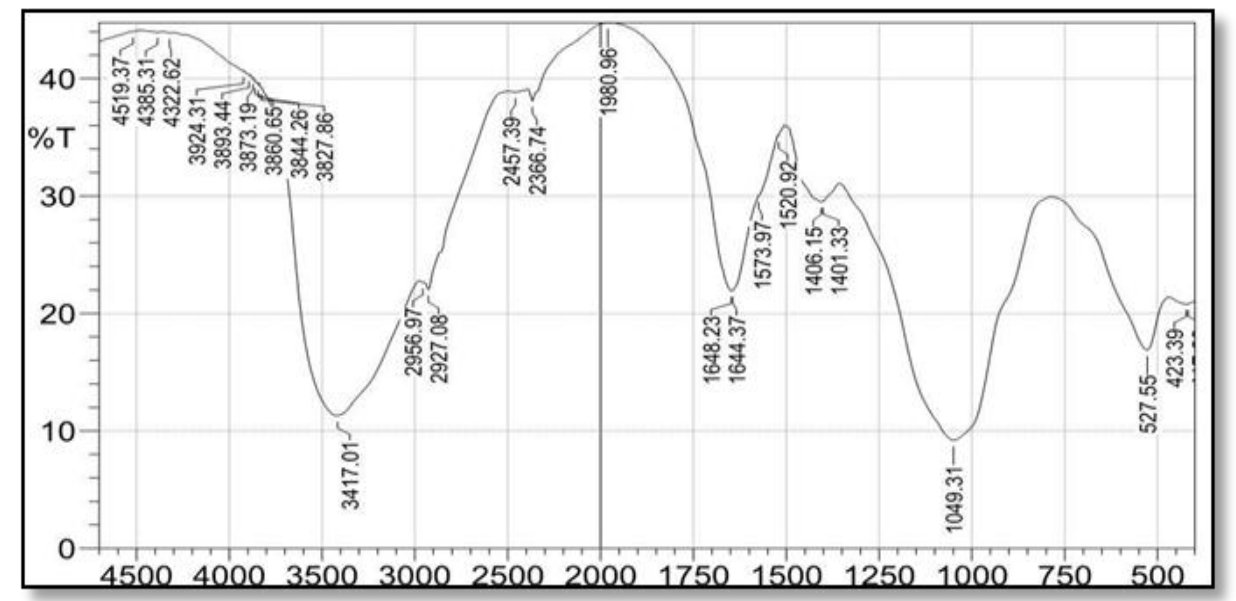

Fig. 4. FTIR of the partially purified bioflocculant produced by P. cibarius H41A KF207755.

The chemical composition analyses of $P$. cibarius H41A KF207755 bioflocculant were carried out and the results indicated that protein and carbohydrates contents were higher than lipids, which indicated that the bioflocculant was mostly glycoproteinalso Okaiyeto et al. (2015) revealed that their bioflocculant; MBF-UFH was composed of both 
polysaccharide and protein; this showed that the flocculation process might involve multiple functional moieties from both polysaccharide and protein. Multiple functional moieties imply many adsorption sites for the kaolin particles, which led to the high flocculating efficiency observed with bioflocculant (Verma et al., 2012).

The SEM images of P.cibarius H41A KF207755 bioflocculant were taken and showed an amorphous structure of a compact nature also reported by Okaiyetoet al. (2015). Its configuration might be accountable for its high flocculation efficiency. They also stated that before the flocculation process, the kaolin clay particles appeared to be fine and scattered, and after the flocculation process, the functional moieties in the molecular chain of bioflocculantwere used for attachment on the kaolin clay particle. Consequently, the interaction between the bioflocculant and kaolin clay particle resulted in the formation of flocs that later aggregated to larger sized flocs, which precipitated out of the suspension as the result of gravity. This observation showed that bridging played a vital role in the flocculation process (Ugbenyen and Okoh, 2014).

The presence of COO- group which referred to the peaks at $1401.33 \& 1406.15 \mathrm{~cm}^{-1}$ provides more adsorption sites for particle attachment, so many particles can be adsorbed to the long molecular chain of the bioflocculant (Luo et al., 2014).Furthermore, the presence of sugar moieties were detected (Sathiyanarayanan et al., 2013). The presence of amide group belongs to the broad peak 3417.01 matches with the result obtained by $\mathrm{He}$ et al. (2010) and Kavita et al. (2013). A weak peak observed at $2366.74 \mathrm{~cm}^{-1}$ was either $\mathrm{CO}_{2}$ adsorption or may be from the amine group (Ahluwalia and Goyal,2005), Presence of signals at $1648 \mathrm{~cm}^{-1}, 1520.92 \mathrm{~cm}^{-1}$ and $1573.97 \mathrm{~cm}^{-1}$ were indication to the presence of $\mathrm{C}=\mathrm{O}$ and $\mathrm{N}-\mathrm{H}$ i.e. amines and amides, these results coincided with Alhazmi (2019). The characteristics of the FTIR spectrum showed the presence of amines, amides, carboxyl and $\mathrm{CH}_{3}$ groups were found in the P. cibarius H41A KF207755 bioflocculant structure as the main functional moieties preferred for flocculation as reported by Wan et al. (2013). Many other previous researches reported the presence of hydroxyl and amino groups in the microbial bioflocculants such as that produced by Pseudomonassp. 38A (Farag et al., 2014) and B. velezensis 40B (Zaki et al., 2013). In addition, Abd El-Salam et al. (2017) indicated a broad stretching intense peak at $3425 \mathrm{~cm}^{-1}$ demonstrated the presence of hydroxyl and amino groups. The weak stretching band detected at $2927 \mathrm{~cm}^{-1}$ revealed the presence of aliphatic $\mathrm{CAH}$ stretching. The broad peak at $2460 \mathrm{~cm}^{-1}$ was characteristic of NAH group.

\section{Biosynthesis and evaluation of AgNPs}

The flasks containing both the bioflocculant and $\mathrm{AgNO}_{3}$ mixtures showed yellowish to brown color after $24 \mathrm{~h}$ of incubation. Typical reaction mixtures contained equal volumes of supernatant and $0.5,1.0$, and $2.0 \mathrm{mM}$ silver nitrate solution. The appearance of the yellowish brown color was an indication of the formation of colloidal AgNPs in the medium and there is no color change in the control flask incubated in the same environment. In the present study, $\mathrm{pH} 11$ supported the maximum synthesis of AgNPs. 
On the other hand $\mathrm{AgNO}_{3}$ solution with bioflocculant, which incubated at different $\mathrm{pH}$ (7-9) showed no synthesis of AgNPs. Concentration of $2.0 \mathrm{mM}$ silver nitrate solution at $\mathrm{pH} 11$ gave the deepest brown color indicating the maximum synthesis of silver nanoparticles (Fig. 5).

The synthesis of well-dispersed, single silver nanoparticles was accomplished via the treatment with the bioflocculant produced by $P$. cibarius H41A KF207755 as a reducing and stabilizing agent. The appearance of the brown color is due to excitation of surface plasmon resonances (SPR) in metal as reported by Hamedi et al. (2012) and Mondal et al. (2012). In agreement with our result, Zaki et al. (2014) reported that UV-vis showed a peak at $\sim 420 \mathrm{~nm}$ corresponding to the plasmon absorbance of nanosilver. Also, absorbance intensity provided indication on the reduction, productivity, and amount of $\mathrm{Ag}^{+}$ion (Hamedi et al., 2012). This may be due to the availability of more reducing biomolecules and concentrations of AgNPs.

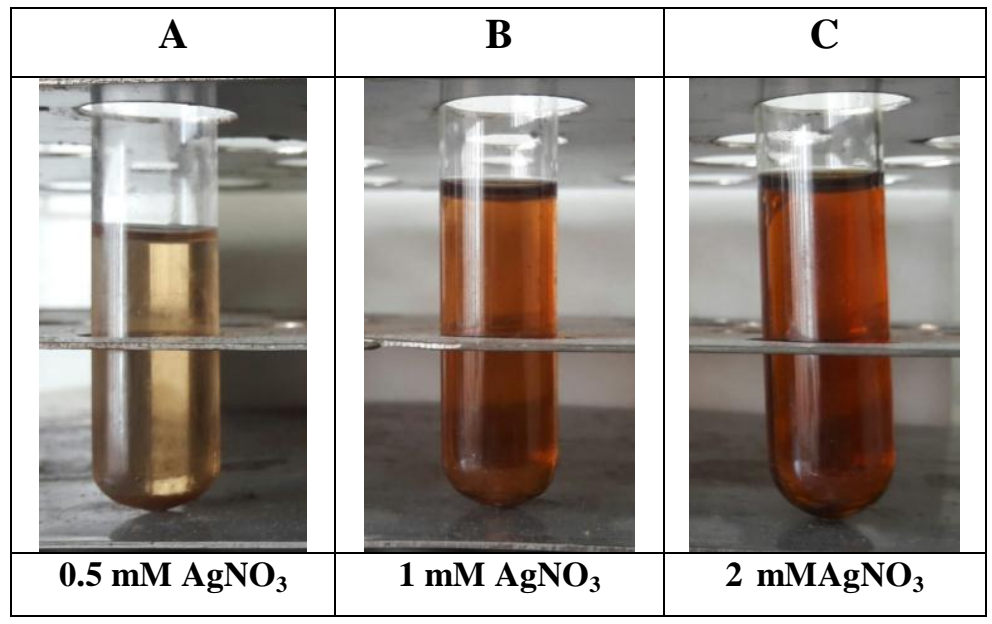

Fig. 5. Culture tubes containing cell filtrate and different concentration of $\mathrm{AgNO}_{3}$ solution with a ratio of $1: 1$ at $\mathrm{pH} 11$. All of them were maintained under the same conditions for $24 \mathrm{~h}$ of reaction in dark at $30^{\circ} \mathrm{C}$.

\section{Characterization of AgNP}

The synthesis of AgNPs by P. cibarius H41A KF207755 was further confirmed by observing the solution in the UV-vis spectrophotometry. UV-vis absorption spectrum of the (bioflocculant and $2.0 \mathrm{mM} \mathrm{AgNO}_{3}$ solution) showed the surface Plasmon resonance derived from the AgNPs at around 369-451 nm (Fig. 6A). The stability of the produced AgNPS extended to 16 months which confirmed by the UV vis spectrophotometry (Fig, $6 \mathrm{~B}$ ), it was observed that AgNPs peaks remained close between $360 \mathrm{~nm}$ to 449 . In addition, the purified AgNPs were then characterized by the bright field of TEM micrograph to determine the size and morphology of AgNPs. Results in Fig. 7 revealed that size of particles was ranged from 1.31 to $17.45 \mathrm{~nm}$ and they are relatively polydispersed-spherical and prismal shape and agglomerated particles were not observed in TEM analysis. The TEM profile has been employed to characterize the size, shape, and 
morphologies of the formed AgNPs. Particles with high density will appear darker in the TEM (Lei, 2007). These nanoparticles are polydisperse and varying in size which ranges from 1.31 to $17.45 \mathrm{~nm}$ and shape, which mainly includes nanospheres and nanoprisms; such variation in shape and size of nanoparticles synthesized by biological systems is common (Bubey et al. 2009). After 16 months, the silver nanoparticles peaks remained close to the first result which indicates that the particles were well dispersed in the bioflocculant solution and there was not much aggregation, whereas previous studies stay stable for 5 months (Sathiyanarayanan et al., 2013).

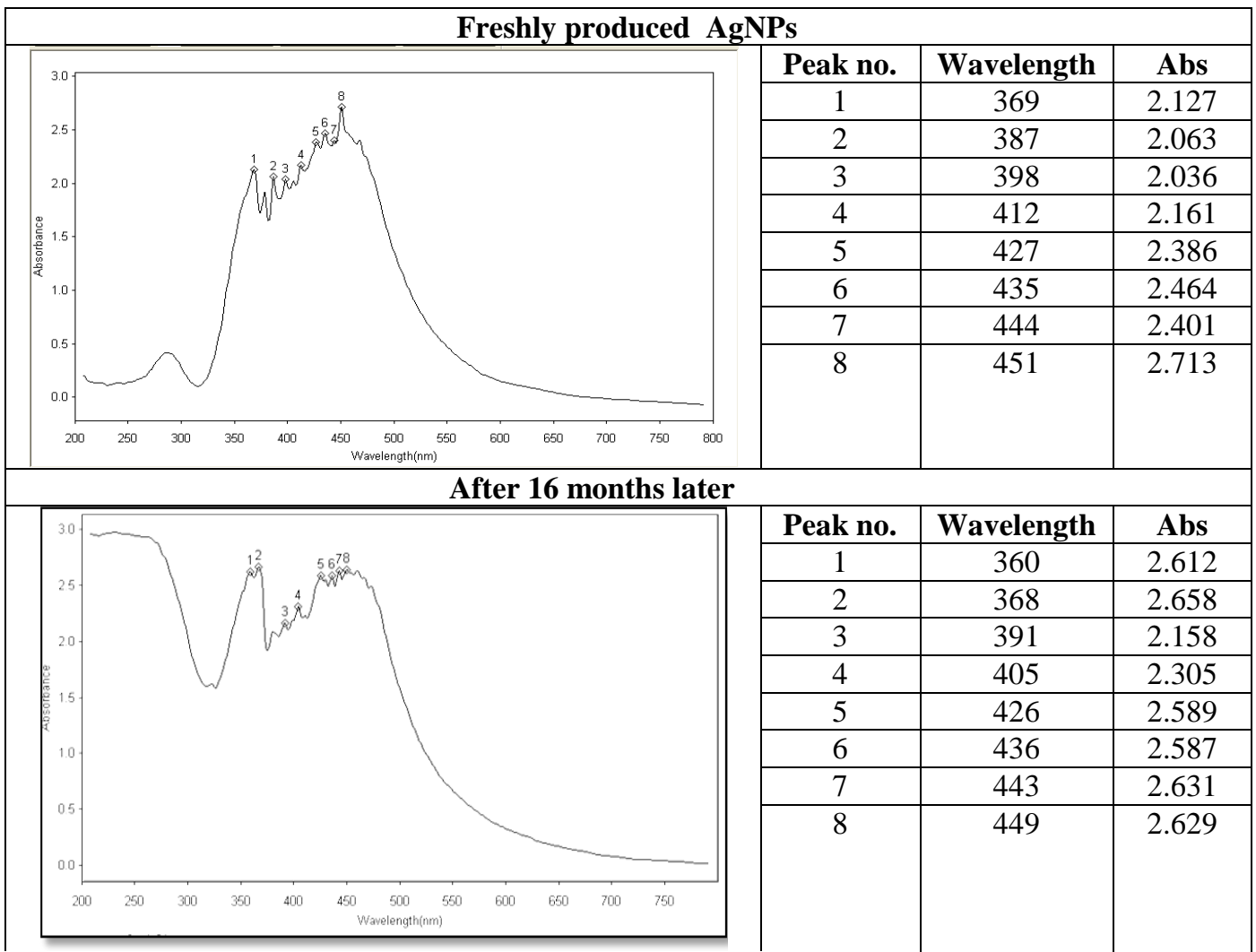

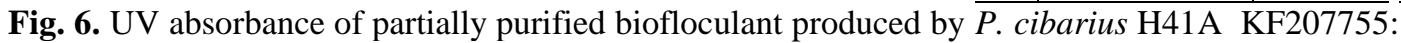
(A) freshly produced and (B) after 16 months of storage.

\section{Antimicrobial activity of AgNP by $P$. cibarius H41A KF207755 bioflocculant}

As shown in Table 3 the antimicrobial activity was evaluated against six bacterial pathogens besides one yeast strain as mentioned before. After incubation period, inhibition zones $(\mathrm{mm})$ were detected against all pathogens except E. faecalis ATCC 29212. In particular, the activity ranged from $21 \mathrm{~mm}$ (C. albicans ATCC 10231) to 32 mm against ( $P$. aeruginosa ATCC 9027). However, these findings confirmed the wide range of antimicrobial property of the nano-silver synthesized by the bioflocculant of $P$. cibarius H41A KF207755. The bactericidal activity of AgNPs was highly comparable with the results of Kim et al. (2008) and AgNPs shown a broad spectrum activity and 
which was similar with the results obtained from other workers who synthesized AgNPs using plant based polysaccharides (Santos et al., 2017; Xia et al., 2017).
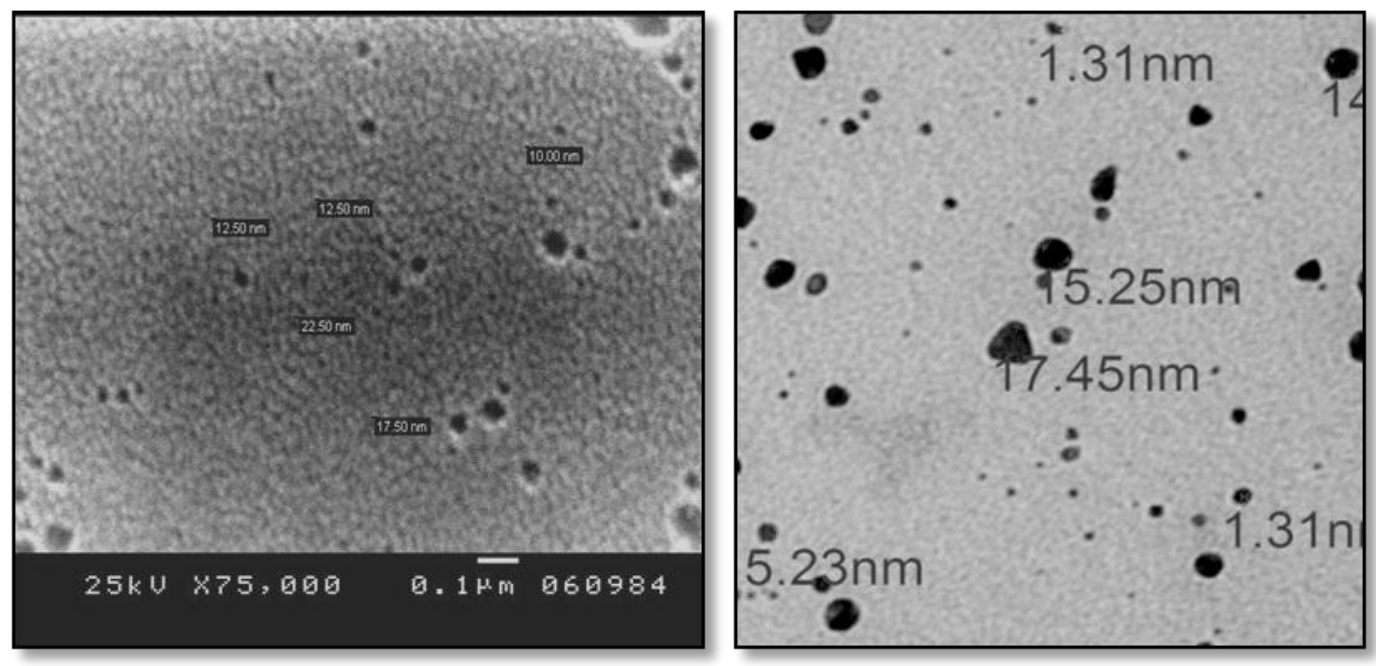

Fig. 7. TEM images recorded from the drop-coated film of the silver nanoparticles synthesized by the silver nitrate solution with $P$. cibarius H41A KF207755 partially purified bioflocculant.

Table 3. Antimicrobial activity of AgNPs by $P$.cibarius $\mathrm{H} 41 \mathrm{~A}$ KF207755 bioflocculant.

\begin{tabular}{lc}
\hline Microbial pathogen & Inhibition zone $(\mathbf{m m})$ \\
\hline S. aureus ATCC 25923 & 30 \\
P. aeruginosa ATCC 9027 & 32 \\
B. subtilis ATCC 6633 & 25 \\
E. faecalis ATCC 29212 & No activity \\
K. pneumonia ATCC 13883 & 28 \\
C. albicans ATCC 10231 & 21 \\
\hline
\end{tabular}

\section{Effect of storage conditions}

Antibacterial effect of AgNPs was tested every 45 days until 16 months later, and nearly similar results were detected which revealed the stability of the compound. Also UV-vis spectrophotometry results after 16 months confirmed the same results (Fig. 6).

\section{Jar test determination of bioflocculant dosage}

The effect of biofloculant dosage on flocculation efficiency for kaolin clay suspension was examined in an attempt to determine the most cost-effective dose for flocculation process. A range of concentrations from 0.3 to $5.0 \mathrm{mgmL}^{-1}$ were prepared for the purified bioflocculant and then their flocculating activities were estimated against $5 \mathrm{gL}^{-1}$ kaolin clay suspension. The concentration dosage that gave the optimum flocculating activity (92.5\%) was $4.0 \mathrm{mgmL}^{-1}$. By increasing the concentration of the biofloculant, no increase in the activity has been achieved. Data in Fig. 8 exhibited the efficiency of the purified bioflocculant in precipitating kaolin clay. 


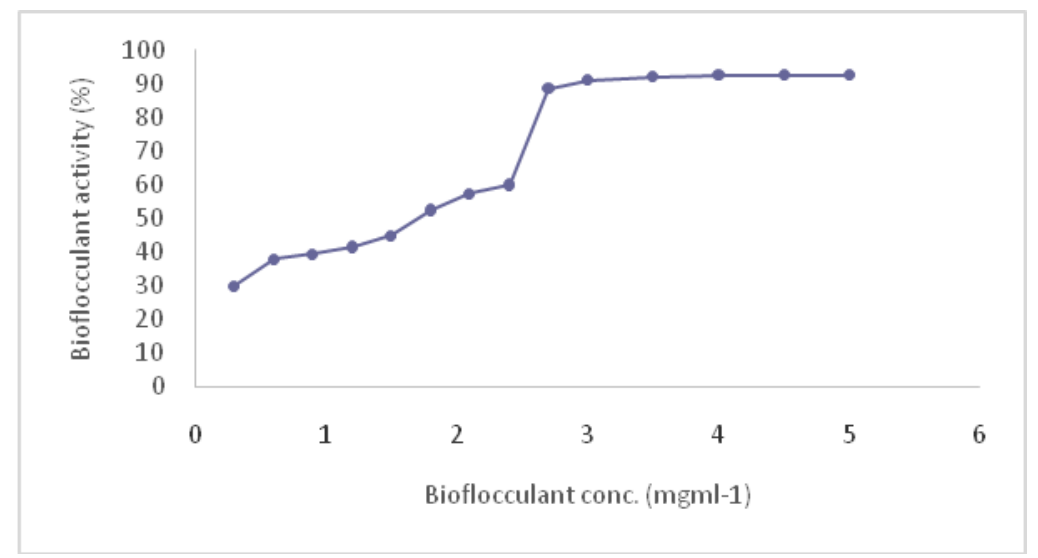

Fig. 9. Bioflocculant dosage in relation to kaolin clay precipitation.

Under optimal conditions, the maximum flocculating activity is usually attained at the optimal bioflocculant dosage (Salehizadeh and Yan, 2014). Okaiyeto et al. (2015) investigated the flocculating activity of purified MBF-UFH in a range of $0.01-0.5 \mathrm{mgmL}^{-}$ 1 . The highest flocculating activity of $92.6 \%$ attained at $0.3 \mathrm{mgmL}^{-1}$. The decrease in flocculating activity of MBF-UFH observed at $0.5 \mathrm{mgmL}^{-1}$ might be due to the over addition of the negatively-charged MBF-UFH, generating strong repulsive forces between the kaolin clay particles and the bioflocculant. These processes restabilized the suspended particles, increasing the viscosity of the suspension, blocking the adsorption sites and noticeably reduced floc formation (Yuan et al., 2011). The results of the above mentioned authors coincided with our results where the optimum dosage in this work was $0.4 \mathrm{mgmL}^{-1}(92.5 \%)$ and at higher concentration, no increase for the flocculating activity was achieved.

\section{CONCLUSION}

A bioflocculant produced by marine strain; Psychrobacter cibarius H41A KF207755 showed high flocculating activity with high thermal stability. Different factors affectting the production of bioflocculant were examined and resulted in increasing the bioflocculant efficiency up to $94 \%$. Characterization of our partially purified bioflocculant revealed that it was a glycoprotein bioflocculant which had different functional groups with charged moieties which lead to strong bioflocculation process enable us to use it to recover suspended solid materials in aquaculture, waste water and various industrial processes to create a clear environment. The produced AgNPs characterized by their high stability and very small particle size with broad spectrum antimicrobial activity. The bioflocculant obtained from Psychrobacter cibarius H41A KF207755 can be used as a multifunctional material in different areas as aquaculture industry, drinking and wastewater treatment, downstream processing, and fermentation processes .Also production of bacteriocidal AgNPs. 


\section{Acknowledgment}

Authors are greatly grateful to Dr. Madlein Meoawd; Lecturer of Marine Chemistry, for her helping in some technical chemical analysis at NIOF.

\section{Conflict of Interest}

There is no conflict of interest.

\section{REFERENCES}

Abd-Elnaby, H.M.; Abou-Elela, G.M.; Hussein, H., Ghozlan, H.A. and Sabry, S.A. (2019). Characterization and Bioremediation potential of marine psychrotolerant Pseudomonas spp. isolated from the Mediterranean Sea, Egypt. Egyptian J. Aqua. Biol. Fish., 23(4): 669-683.

Abd El-Salam, A.E.; Abd-El-Haleem, D.; Youssef, A.S.; Zaki, S.; Abu-Elreesh, G. and El Assar, S.A. (2017). Isolation, characterization, optimization, immobilization and batch fermentation of bioflocculant produced by Bacillus aryabhattai strain PSK1. J. Gene. Engin. Biotechnol., 15: 335-344.

Agunbiade, M.O.; Heerden, E.V.; Pohl C.H. and Ashafa, A.T. (2017). Flocculating performance of a bioflocculant produced by Arthrobacter humicola in sewage waste water treatment. BMC Biotechnol., 17: 51-55.

Ahmad, A.; Mukherjee P.; Senapati, S.; Mandal, D.; Khan, M.; Kumar, R. and Sastry, M.(2003). Extracellular biosynthesis of silver nanoparticles using the fungus Fusarium oxysporum. Colloids Surf. B,28: 313-318.

Ahluwalia, S.S. and Goyal, D. (2005).Removal of heavy metal by waste tea leaves from aqueous solution. Eng. Life Sci., 5: 158-162.

Alhazmi,H.A. (2019). FT-IR Spectroscopy for the identification of binding sites and measurements of the binding interactions of important metal ions with bovine serum albumin. Sci. Pharma., 87:5-8.

Amer, M.S. and Ibrahim, H.A.H. (2019). Chitosan from marine-derived Penicillum spinulosum MH2 cell wall with special emphasis on its antimicrobial and antifouling properties. Egyptian J. Aqua. Res., 45: 359365.

Bhunia, B.; Mukhopadhy, D.; Goswami, S.; Mandal, T. and Dey, A. (2012). Improved production, characterization and flocculation properties of poly $(\gamma)$-glutamic acid produced from Bacillus subtilis. J. Biochem. Technol., (3):389-394.

Bubey, M.; Bhaduria, S. and Kushwaha, B.S. (2009). Green synthesis of nanosilver particles from extract of Eucalyptus hybrid (safeda) leaf, dig. J. Nanomat. Biosturf., (4): 537-543.

Bradford, M.M. (1976). A rapid and sensitive method for the quantitation of microgram quantities of protein utilizing the principle of protein-dye binding. Ana. Biochem., 72: 248-254.

Chaplin, M.F. and Kennedy, J.F. (1994). Carbohydrate Analysis, $2^{\text {nd }}$ ed.; Oxford University Press: New York NY, USA,57.

Deng, S.B.; Bai, R.B.; Hu, X.M. and Luo, Q. (2003). Characteristics of a bioflocculant produced by Bacillus mucilaginosus and its use in starch wastewater treatment. Appl.Microbiol. Biotechnol., 60(5): 588-593. 
Elkady, M.F.; Farag, S.; Zaki, S.; Abu-Elreesh, G. and Abd-El-Haleem, D. (2011). Bacillus mojavensis strain 32A, a bioflocculant-producing bacterium isolated from an Egyptian salt production pond. Biores. Technol., 102: 81438151.

Farag, S.; Elkady, Z.M. and Abd-El-Haleem, D. (2014).Production and characteristics of a bioflocculant produced by Pseudomonas sp. strain 38A.J. Adv. Biol., 4:286-295.

Frings, C.S.; Fendley, T.W.; Dunn, R.T. and Queen, C.A. (1971). Improved determination of total serum lipids by the Sulfo-phospho-Vanillin Reaction. J. Clin. Chem., 18: 7-11.

Gao, J.; Bao, H.Y.; Xin, M.X..; Liu, Y.X.; Li, Q. and Zhang, Y.F. (2006). Characterization of a bioflocculantfrom a newly isolated Vagococcus sp. W31. J. Zheijang University SCIENCEB, 7: 186-192.

Gao, Q.; Zhu, X.-H.; Mu, J.; Zhang, Y. and Dong, X.W. (2009). Using Rudita pesphilippinarum conglutination mud to produce bioflocculant and its applications in wastewater treatment. Biores. Technol., 100: 4996-5001.

Gong, W.;Wang, S.; Sun, X.F.; Liu, X.;Yue, Q. and Gao, B. (2008). Bioflocculant production by culture of Serratia ficaria and its application in wastewater treatment.Biores. Technol., 99(11): 4668-4674.

Hamedi, S.; Ghaseminezhad, S.M.; Shojaosadati, S.A. and Shokrollahzadeh, S. (2012). Comparative study on silver nanoparticles properties produced by green methods. Iranian J. Biotechnol., 10(3): 191-197.

Hashim, N.F.C.; Ghazali, N.A.; Amin, N.M.; Ismail, N. and Kasan, N.A (2019). Characterization of marine bioflocculant-producing bacteria isolated from Biofloc of Pacific Whiteleg shrimp, Litopenaeus vannamei culture ponds. IOP Conf. Series: Earth and Environmental Science $2460120074^{\text {th }}$ International Conference on Tropical and Coastal Region Eco Developmental Science.

He, J.; Zou, J.; Shao, Z.; Zhang, J.; Liu, Z. and Yu, Z. (2010).Characteristics and flocculating mechanism of a novel bioflocculant HBF-3 produced by deep-sea bacterium mutant Halomonas sp. V3a.World J. Microb. Biot.,26: 1135-1141.

Jie, G.; Huaying, B.; Ming-Xiu, X.; Yuanxia, L.; Qian, L. and Yanfen, Z. (2006). Characterization of a bioflocculant from a newly isolatedVagococcus sp. W31. J Zhejiang University SCIENCE B, 7(3): 186-192.

Kavita, K.; Mishra, A. and Jha, B.(2013). Extracellular polymeric substances from two biofilm forming Vibrio species: Characterization and applications. Carbohydr Polym 94, 882-888.

Kim, K.; Jun, W.S.; Sung, S.; Moon, K.; Choi, J.S.; Kim, J.G. and Lee, D.G. (2008). Antifungal effect of silver nanoparticles on dermatophytes. J. Microbiol. Biotechnol., 18: 1482-1484.

Korshed, P.; Li, L.;Ngo, D. and Wang, T. (2018). Effect of storage conditions on the long-term stability of bactericidal effects for laser generated silver nanoparticles. Nanomat., 8(4): 218-222.

Kurane, R. and Matsuyama, H. (1994). Production of a bioflocculant by mixed culture. Biosci. Biotechnol. Biochem., 58: 1589-1594. 
Kurane, R. and Nohata, Y. (1997). Complete defined medium for largescale production of polysaccharide bioabsorbent from Alcaligenes latus B-16. Agricul. Biol. Chem.,83: 116-117.

Kurane, R.; Hatamochi, K.; Kakuno, T.; Kiyohara, M.; Hirano, M. and Taniguchi, Y. (1994).Production of a bioflocculant by Rhodococcus erythropolis S-1 grown on alcohols. Biosci. Biotech. Bioch., 58(2): 428-429.

Landage, S.M. and Wasif, A.I. (2012).Nanosilver-an effective antimicrobial agent for finishing textile. IJESET, 4: 66-78.

Lei, G. (2007). Synthesis of nano-silver colloids and their anti-microbial effects [M.S. thesis], Faculty of the Virginia Polytechnic Institute and State University.

https://vtechworks.lib.vt.edu/bitstream/handle/10919/31915/Synthesis_of_Na no-Silver_Colloids_and_Their_Anti-Microbial_Effects.pdf?sequence $=1$

Li, Y.; He, N.; Guan, H.; Du, G. and Chen, J. (2003). .A novel polygalacturonic acid bioflocculant REA-11 produced by Corynebacterium glutamicum: a proposed biosynthetic pathway and experimental confirmation," Appl. Microbiol. Biotechnol., 63(2): 200-206.

Liu, W.; Wang, K.; Li, B.; Yuan, H. and Yang, J. (2010). Production and characterization of an intracellular bioflocculant by Chryseobacterium daeguense W6 cultured in low nutrition medium. Biores. Technol., 101:1044-1048.

Luo, Z., Chen, L., Chen, C., Zhang, W., Liu, M., Han, Y. and Zhou, J.(2014).Production and characteristics of a bioflocculant by Klebsiella pneumonia YZ-6 isolated from human saliva. Appl. Biochem. Biotechnol., 172: $1282-1292$.

Luo, l.; Zhao, Z.; Huang, X.; Du, X.; Wang, C.; Li, J.; Wang, L. and Xu., Q. (2016). Isolation, identification, and optimization of culture conditions of a bioflocculant-producing bacterium Bacillus megaterium SP1 and its application in aquaculture wastewater treatment. Article ID 2758168 | 9 pages |

Mathias, D.; Hammantola, S. and Ishaku, G. (2017). Isolation and characterization of bioflocculant producing bacteria from wastewater at Jimeta, Adamawa State. J. Adv. Biol. Biotechnol., 15(1): 1-7.

Mondal, A.K.; Mondal, S.; Samanta S. and Mallick, S. (2012). Synthesis of ecofriendly silver interrelationship. Adv. Biores., 2: 122-133.

Nwodo, U.U.; Agunbiade, M.O.; Green, E.; Mabinya, L.V. and Okoh, A.I. (2012). A Freshwater Streptomyces, isolated from Tyume River, produces a predominantly extracellular glycoprotein bioflocculant. Int. J. Mol. Sci., 13: 8679-8695.

Okaiyeto, K.; Nwodo, U.U.; Mabinya, L.V.; Okoli, A.S. and Okoh, A.I. (2015). Characterization of a bioflocculant (MBF-UFH) produced by Bacillus sp. AEMREG7. Int. J. Mole. Sci., 16: 12986-13003.

Pan, Y.; Shi, B. and Zhang, Y. (2009). Research on flocculation property of bioflocculant PG.a21 Ca. Modern Appl Sci 3(6): 106-112. 
Patrick, S. and Finn, B. (2008). in: McNeil, B. and Harvey, L.M. (Eds.), Practical fermentation technology, John Wiley and Sons Inc., UK, pp. 69-95. ISBN 978-0470-014349.

Salehizadeh, H. and Yan, N. (2014). Recent advances in extracellular biopolymer flocculants. Biotochnol. Adv., 32(8): 1506-1522.

Santos, C.A.; Balcão, V.M.; Chaud, M.V.; Seckler, M.M.; Rai, M. and Vila, M.M.D.C. (2017). Production, stabilization and characterization of silver nanoparticles coated with bioactive polymers pluronic F68, PVP and PVA. IET Nanobiotechnol., 11(4): 411-419.

Sathiyanarayanan, G.; Kiran, G.S. and Selvin, J. (2013). Synthesis of silver nanoparticles by polysaccharide bioflocculant produced from marine Bacillus subtilis MSBN17. Colloids and Surfaces B: Biointerfaces., 102: 13-20.

Shahadat, M.; Teng, T.; Rafatullah, M.; Shaikh, Z.A.; Sreekrishnan, T.R., and Ali, S. (2017). Bacterial bioflocculants: A review of recent advances and perspectives. Chem. Enging. J., (328): 1139-1152.

Shahverdi, A.R.; Minaeian, S.; Shahverdi, H.R.; Jamalifar, H. and Nohi, A.A. (2007). Rapid synthesis of silver nanoparticles using culture supernatants of Enterobacteria: a novel biological approach. Process Biochem., 42(5):, 919-923.

Silambarasan, S. and Abraham, J. (2013).Biosynthesis of silver nanoparticles. Afr. J. Biotechnol., 12: 3088-3098.

Tang, W.; Song, L.; Li, D.; Qiao J.; Zhao, T. and Zhao, H. (2014). Production, characterization and flocculation mechanism of cation independent, $\mathrm{pH}$ tolerant and thermal stability bioflocculant from Enterococcus sp. ETH-2. PLoS ONE J., 9(12): 1-19.

Ugbenyen, A.M.; Cosa, S.; Mabinya, L.V. and Okoh, A.I. (2014). Bioflocculant production by Bacillus sp. Gilbert isolated from a marine environment in South Africa. Appl. Biochem. Microbiol., 50: 49-54.

Ugbenyen, A.M. and Okoh, A.I. (2014). Characteristics of a bioflocculant produced by a consortium of Cobetia and Bacillus species and its application in the treatment of wastewaters. Water SA, 40: 139-144.

Verma, A.K.; Dash, R.R. and Bhunia, P. (2012). A review on chemical coagulation/fiocculation technologies for removal of color from textile wastewaters. J. Environ. Manag. 93: 154-168.

Wang, L.; Ma, F.,; Lee, D.; Wang, A. and Ren, N. (2013). Bioflocculants from hydrolysates of corns stover using isolated strain Ochrobactium cicero W2. Biores. Technol., 145:259-263.

Wan, C.; Zhao, X.Q.; Guo, S.L.; Alam, M.A. and Bai, F.W. (2013).Bioflocculant production from Solibacillus silvestris W01 and its application in cost-effective harvest of marine microalga Nannochloropsis oceanica by flocculation. Bioresour. Technol., 135: 207-212.

Xia, S.Q..; Zhang, Z.Q.; Wang, X.J.; Yang, A.; Chen, L.; Zhao, J.F.; Leonard, D. and Jaffrezic-Renault, N. (2008). Production and characterization of a bioflocculant by Proteus mirabilis TJ-1. Biores. Technol., 99(14): 6520-6527. 
Xia， Q.H.; Zheng， L.P.; Zhao， P.F. and Wang， J.W. (2017). Biosynthesis of silver nanoparticles using Artemisia annuacallus for inhibiting stem-end bacteria in cut carnation flowers. IET Nanobiotechnol., 11(5): 552-556.

Yim, J.H.; Kim, S.J.; Ahn, S.H. and Lee, H.K. (2007). Characterization of a novel bioflocculant, $\mathrm{p}-\mathrm{KG} 03$, from a marine dinoflagellate, Gyrodinium impudicum KG03. Biores. Technol., 98:361-367.

Yin, Y.J.; Tian, Z.M.; Tang, W.; Li, L.; Song, L-Y. and McElmurry, S.P. (2014). Production and characterization of high efficiency bioflocculant isolated from Klebsiella sp. ZZ-3. Biores. Technol., 171: 336-342.

Yuan, S.J.; Sun, M.; Sheng, G.P.; Li, Y.; Li, W.W.; Yao, R.S. and Yu, H.Q. (2011). Identification of key constituents and structure of the extracellular polymeric substances excreted by Bacillus megaterium TF10 for their flocculation capacity. J. Environ. Sci. Technol.45: 1152-1157.

Zaki, S.; Etarahony, M.; Elkady, M. and Abd-El-Haleem, D. (2014). The use of bioflocculant and bioflocculant-producingBacillusmojavensisstrain 32A to synthesize silver nanoparticles.Hindawi Publishing Corporation Journal of Nanomaterials Volume 2014, Article ID 431089, 7 pages.

Zaki, S.; Farag S.; Abu-Elreesh G.; Elkady, M.; Nosier, M. and Abd-ElHaleem D. (2011). Characterization of bioflocculants produced by bacteria isolated from crude petroleum oil. Int. J. Environ. Sci. Technol., 8(4): 831840.

Zaki, S.A..; Elkady, M.F.; Fareg, S. and Abd-EI-Haleem, D. (2013). Characterization and flocculation properties of a carbohydrate bioflocculant from a newly isolated Bacillus velezensis 40B. J. Environ. Biol., 34: 51-58.

Zaki, S.; Etarahony, M.; Elkady, M. and Abd-El-Haleem, D. (2014). The use of bioflocculant and bioflocculant-producing Bacillus mojavensis strain 32a to synthesize silver nanoparticles. J. Nanomat., 1-7.

Zhao, H.J.; Liu, H.T. and Zhou, J.G. (2013). Characterization of a biofiocculant MBF-5 by Klebsiella pneumoniae and its application in Acanthamoeba cysts removal. Biores. Technol., 137: 226-232.

Zheng, Y.; Ye, Z.L.; Fang, X.L.; Li, Y.H. and Cai, W.M. (2008). Production and characteristics of a bioflocculant produced by Bacillus sp. F19. Biores. Technol., 99(16): 7686-7691. 